\title{
Research on Campus Emergencies Management of Private Universities in New Media Era
}

\author{
Yan Zhao \\ Ideological and Political Department \\ Xi'an Peihua University \\ Xi'an, Shaanxi 710125, China \\ e-mail: qianyanzhao@yeah.net
}

\begin{abstract}
With the development of information technology, a variety of new media emerge in an endless stream and is widely used for college students. The new media is not only changing the way of information dissemination, but also playing an important role in the dissemination of public opinion of university emergencies. Due to the new characteristics of rapidity, interactivity and diffusion for new media, the respond to emergencies for university is often in a very passive situation, and thus may cause irreparable damage. Therefore, understanding public opinion dissemination mechanism and characteristics of the new media environment of university emergencies is very important. By taking corresponding countermeasures for scientific disposal, the emergencies of public opinion could be mastered, that may improve emergencies management level. This paper describes the characteristics of the campus emergencies management of private universities in new media era firstly. Then by analyzing the present situation and the causes of campus emergencies, strategies for coping with the emergencies are given. Such include forming a complete set of coping strategies through the network monitoring, mastering information, establishing the news spokesman system. Meanwhile, using the traditional media and public opinion guidance, would be good for reversing the passive situation and reshaping the image of school.
\end{abstract}

Keywords-New Media; Private University; Emergency Management

\section{INTRODUCTION}

During the period of social transformation of university, public safety emergencies in colleges and universities are frequent. All kinds of emergencies on the development of national higher education, the legitimate rights and interests of teachers and students, the reputation of institutions of higher learning are caused by different harm degree, especially the survival and development of private colleges has been a greater impact. Under the highly developed network information age, the teachers and students in colleges and universities, as a special audience, has a normal users more active sensitive thinking and response, and more in the field of public opinion in the high frequency of interaction. The popularity of new media makes it possible for everyone to be a publisher of information and disseminators of public information. In recent years, a series of college emergencies have encountered the network siege of campus public opinion field. By the simple criminal cases, disappearance would be extended to the network of social group, or even negative emotions between teachers and students, and then extended to the whole society, the huge impact and influence of reputation. This situation not only caused the attention of the communication circle, but also aroused the attention of university administrators.

\section{RELATED THEORIES OF EMERGENCY MANAGEMENT OF COLLEGE CAMPUSES IN PRIVATE COLLEGES}

\section{A. Campus emergencies management}

In order to define the meaning of campus emergencies in private universities, the following factors should be clarified. Firstly, the subject of the event is the teachers and students of private universities and private universities. Secondly, the occurrence of the incident occurred in the campus of the private university or in the campus, which was related to the members of the campus. Thirdly, the nature is sudden. Fourthly, in degree, it is or may cause serious harm. Fifthly, some reasons can induce campus emergencies, such as public security, security, public health, and other abnormal deaths. Sixthly, measures must be taken to take emergency measures.

Based on the above analysis, we can overview the meaning of private colleges campus emergency is: in private colleges or in private colleges teachers and students as the main body, because public security, security, public health, crime and so on the reason of the wrongful death of adverse impact on society, schools, teachers and students, or may cause serious damage, need to take emergency measures to deal with all aspects of the event.

\section{B. Emergency management in the campus of the private university}

Private colleges campus emergency management, is refers to the school authorities and the main leadership (usually the principal) to avoid possible and realistic school of emergencies, reduce emergency situation brought about by the serious threat, establish emergency management team, develop a plan of emergency management, the school may the unexpected accidents and the reality of prevention, treatment and evaluation of management strategy. Campus 
emergency management is divided into three stages: precautionary prevention, handling and post-mortem.

\section{Characteristics and hazards of campus emergencies in the new media era}

The popularity of new media, makes everyone could become the publisher of information, public information dissemination, more evolved into the whole social phenomenon, and the "information network transmission structure form, the information transmission ability of each individual to exponential amplification, form the fission effect, information dissemination and stereo effect. Colleges and universities in recent years, a series of unexpected events, frequently encountering campus network public opinion field siege, is originally. By a simple criminal case, disappearance, but due to the disposal of mistake: a lot of leadership of the emergencies in colleges and universities in the sudden incident, the first thought of the processing method is a cover-up, buck-passing, elaborate the media. Lead to further intensify contradictions, extended to the network of social group, or even negative emotions between teachers and students. That may eventually make the media into opposition, and make the follow-up work into a passive site. So the reputations of universities have a huge impact and influence.

\section{CURRENT SITUATION AND PROBLEM ANALYSIS OF EMERGENCY MANAGEMENT IN PRIVATE UNIVERSITIES}

\section{A. Lack of perfect system}

Due to subjective and objective reasons, some private colleges not strictly comply with national requirements, will set up the system of emergency management, this leads to a safe security system is not perfect, the lack of a clear appeal way between teachers and students, not to carry out the supervision and inspection work, these will make emergency risk increase, part of private colleges has also formulated the measures, but not really implemented.

\section{B. Awareness of emergencies is not strong}

Many colleges and universities especially private colleges usually lack of organization members to emergency consciousness education, teachers and students not only know the basic types of emergencies such as common sense, more do not know how to deal with emergencies. The current universities focus more on the students' classroom education, ignoring the actual combat drills and game design. So when students face the conflicts between themselves and other students and teachers, how to deal with and solve problems in the face of external threats and fraud, many students know nothing about it.

\section{Permanent institutions and full-time personnel who lack the intervention of emergencies}

Some colleges simply equate the ideological and political work with emergency intervention, the psychological prevention institutions affiliated in a certain department, under the department of the lack of emergency intervention professional basic knowledge and skills of part-time teacher, not formed by each department leader, school counselor, teacher, medical staff and psychological professionals to participate, unified and complete system of psychological intervention. In the situation of students' psychological stress, they give timely and effective psychological assistance to students. On the other hand, when schools and students to avoid conflict, students in the form of a petition to the school express some interests, if part-time agencies failed to solve the problem, 'would be easy to make small petition evolved into a large-scale violence.

\section{Remediation of post-mortem prevention}

Campus emergency management can be divided into emergency early warning prevention, emergency control and emergency treatment. Emergency early warning prevention can prevent the occurrence of emergencies, eliminate the signs before the occurrence of emergencies, or reduce the extent of their destruction through human effort. However, many colleges and universities in our country, and emergency management mode is the dominant "after mobilization" rather than "prior control" type, daily preparation to prevent, education training, emergency drill are very weak. Often after the occurrence of events, hastily organized institutions and developed solutions.

\section{E. The relevant laws and regulations are not perfect}

At present our country is not specifically for campus emergency management legislation, "criminal law" and "the regulations on administrative penalties for public security" is defined and tackle the problem of campus crime and violating the imputation principles of college student injury cases, the fact that, processing standards is not involved, such as school discipline conflict, teachers and students' injury in the event of violations of the student human rights and other emergency incidents, schools, individuals and what responsibility should assume their respective responsibilities, schools and teachers respectively which administrative responsibility and criminal responsibility, legal liability in the law has not yet been determined..

\section{STRATEGIES FOR COPING WITH THE CRISIS IN THE CAMPUS OF THE PRIVATE UNIVERSITIES IN THE MEDIA ERA}

\section{A. Strengthen the network construction and public opinion monitoring, and enhance the awareness of crisis prevention}

1) Fully realize the importance of public opinion monitoring. Since the media age, colleges and universities at the same time of daily propaganda work, must have consciousness of public opinion monitoring, firmly grasp the network platform, the network real-time monitoring, the official website, the network agenda setting problems such as strengthening management. Accurate real-time grasp the network speech about scientifically, in the shortest possible time get the public opinion direction, through professional public opinion analysis report, for crisis prevention, public opinion later college work provides useful auxiliary.

2) Strengthen the website construction of colleges and universities. College website as the first college network 
platform, directly facing the network audience, thus to build highly effective, the authority, information updates fast, interactive website is one of the highlights of the party propaganda work. But in reality, in most especially private university, the network complaints, netizens mailbox, feedback and other links are often useless - this is the most official website can't give full play to the role of, is difficult to gain credibility. Therefore, the website of colleges and universities can update the speed of the website, and the information feedback should be timely, so as to enhance the interaction with Internet users so as to improve the role of the official website in the online media.

\section{B. Start the emergency response mechanism and actively respond to the disposal}

1) Start the public opinion emergency mechanism in the first place. The first priority of the crisis response mechanism in colleges and universities is to establish a public opinion response leading group, to find out and expose the truth in a timely manner, and to make an objective and clear decision on the nature of the event. The timely clarification of the facts not only shows the attitude of the school, but also provides a strong basis and reference for the subsequent problems, which is more conducive to the investigation of the attribution of responsibility and preemption of public opinion.

2) Establish a press spokesman system. Select one or two candidates who are familiar with the law and media operation rules, and have been trained by professional systems to be the school's press spokesmen. At home, in addition to the spokesman, other leaders at all levels shall have no right to represent the school, must have enough trust to their professional ability, after determine the good thinking, give foreign voice spokesman, ensure that every link of the campus size is consistent, must not contain block at some critical moments, influence news release effect; , a spokesman for the foreign, must bear the responsibility of the media, whether positive or negative public opinion environment, must be quick in the first time to maintain the school image, stable public opinion, follow-up work for the school.

\section{To guide the public opinion after the event and reduce the negative effects}

After the campus emergency, the managers and the propaganda department is not once and for all rest easy, but in a long time, to the university image repair and reshape the image of public opinion, in addition to ideological benign guide for teachers and students, unified thought, strengthen the cohesion, but also set up continuously in the traditional media and network public opinion agenda, for high density of public opinion guidance, with a large number of positive reports to dilute the impact of negative news, as far as possible to reduce the negative effects of crisis to minimum.

\section{REFERENCES}

[1] S. Minfeng: Public opinion transmission and institutional intervention of emergent events in universities in the context of the Internet [J]. Journal of changchun university of technology (social science edition), $2012(1)$

[2] Z. Yanmei: A discussion on the mechanism of emergency handling in colleges and universities [J]. Journal of Jiamusi Education College, 2013 (1)

[3] Z. Ying, Editor of China new media social responsibility research report $2014[\mathrm{M}]$. Beijing: social sciences literature publishing house, 2014.

[4] T. Tao. Research on network public opinion governance [M] Shanghai: Shanghai social science press, 2014

[5] L. Xin. On the language skills of university press speakers [J]. News fan, 2007(18)

[6] T. Tao. Network public opinion research governance in Shanghai: Shanghai Social Science Press, 2014[M]

[7] Z. Ying, Editor in chief. China new media Social Responsibility Research Report 2014[M]. Beijing: Social Sciences Literature Press, 2014. 